\title{
Importance of terms: What is a wealth deposit?
}

\author{
Ester Oras
}

This paper discusses the importance of the terminology used to describe deliberately concealed separate artefact deposits. It is based on material from the eastern Baltic (Estonia, Latvia, Lithuania) 1.-9. century AD. A general overview of the main material characteristics of the source material and relevant research questions is presented. The article then discusses previous traditionally deployed terms and concepts relating to this specific study material (hoards, votive deposits, selective and special deposits etc). The pros and cons of each one of the terms is discussed and the difficulties of employing these concepts in current research is emphasised. A new term, 'wealth deposit', is introduced and discussed in detail. This term is defined as one or more objects of value that are hidden deliberately as an intended deposition of specifically chosen artefacts into a specifically chosen place in a specific manner. I argue that this term-'wealth deposit'-is more appropriate for analysing the development of and changes in depositional practices in time and space, because it does not limit the source material in relation to a deposit's production materials, number of objects, environment of concealment and, more importantly, by preconditioned interpretations as to why the deposit was made in the first place. A case study of Estonian wealth deposits is provided to illustrate the usefulness of this new term.

\section{Introduction}

All research starts with questions and definitions. ${ }^{1}$ The choice and explanation of terms is certainly one of the crucial parts of every study. They limit and expand source material and help to communicate our ideas to the audience. Therefore the problems of naming source material and defining it are no less important than the theoretical implications or interpretations of the data. I would go even further by saying that the terms might even dictate and influence different aspects of a whole research project: its theoretical

\footnotetext{
* Division of Archaeology, Department of Archaeology and Anthropology, University of Cambridge, Downing Street, Cambridge CB2 3DZ, United Kingdom, eo271@cam.ac.uk
}

standpoints, choice of material, methodological approaches and final results.

In this paper I am going to provide an example of the importance of terms that are used in archaeological research. It is based on the concept of deliberately concealed deposits of artefacts and the example material comes from the eastern Baltic 1.-9. century AD. First I demonstrate the variability of my source material, before showing why previously used terms are problematic and not suitable in this case. Finally, I introduce the new term 'wealth deposit' which I find to be more appropriate for my current study and for describing this category of archaeological material. A broader aim of the paper is to provoke thought about terminology in archaeology - both the choice of established terms and the creation of new ones. It pro- 


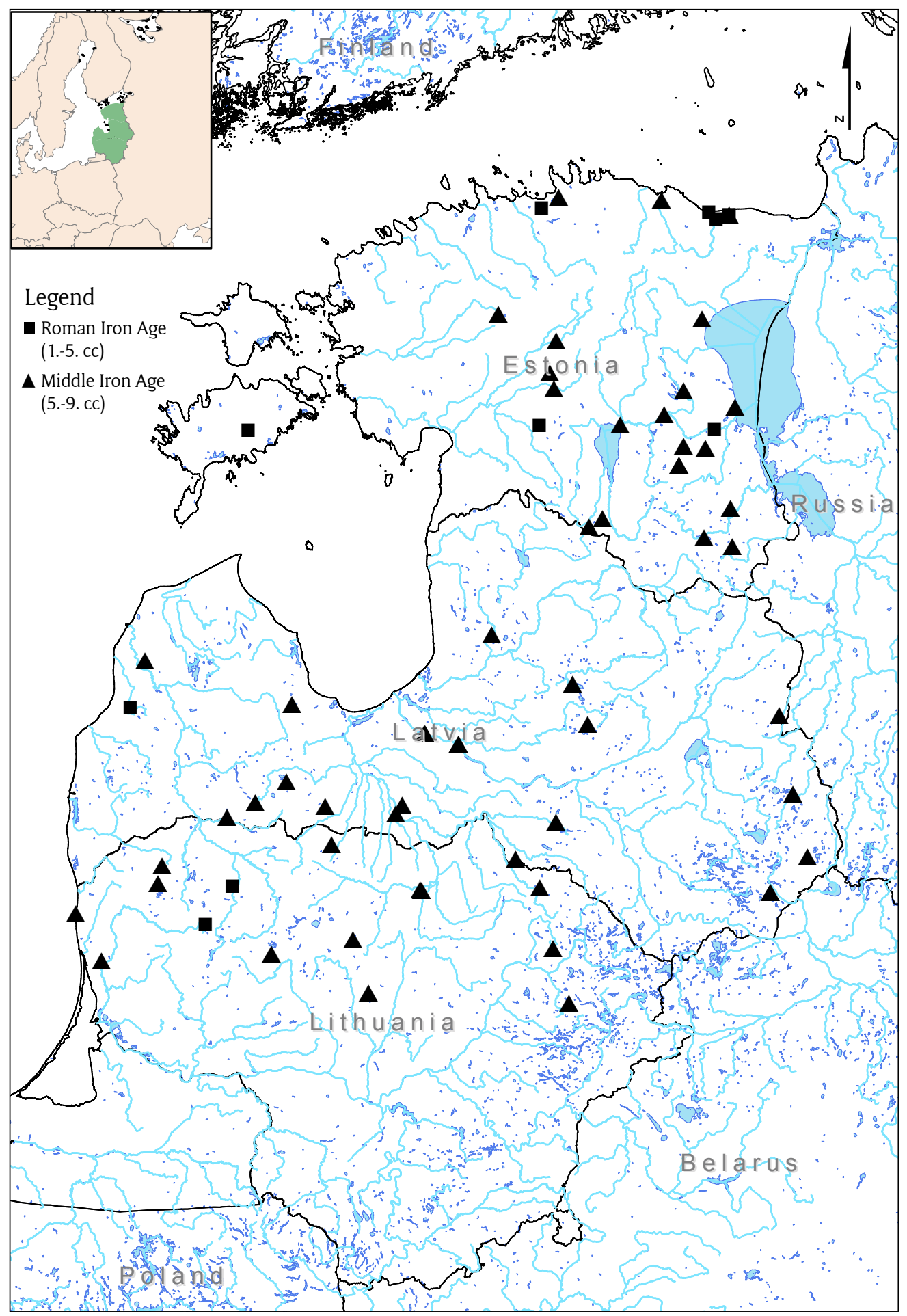

Fig. 1: Distribution map of the eastern Baltic 1.-9. century AD wealth deposits. 


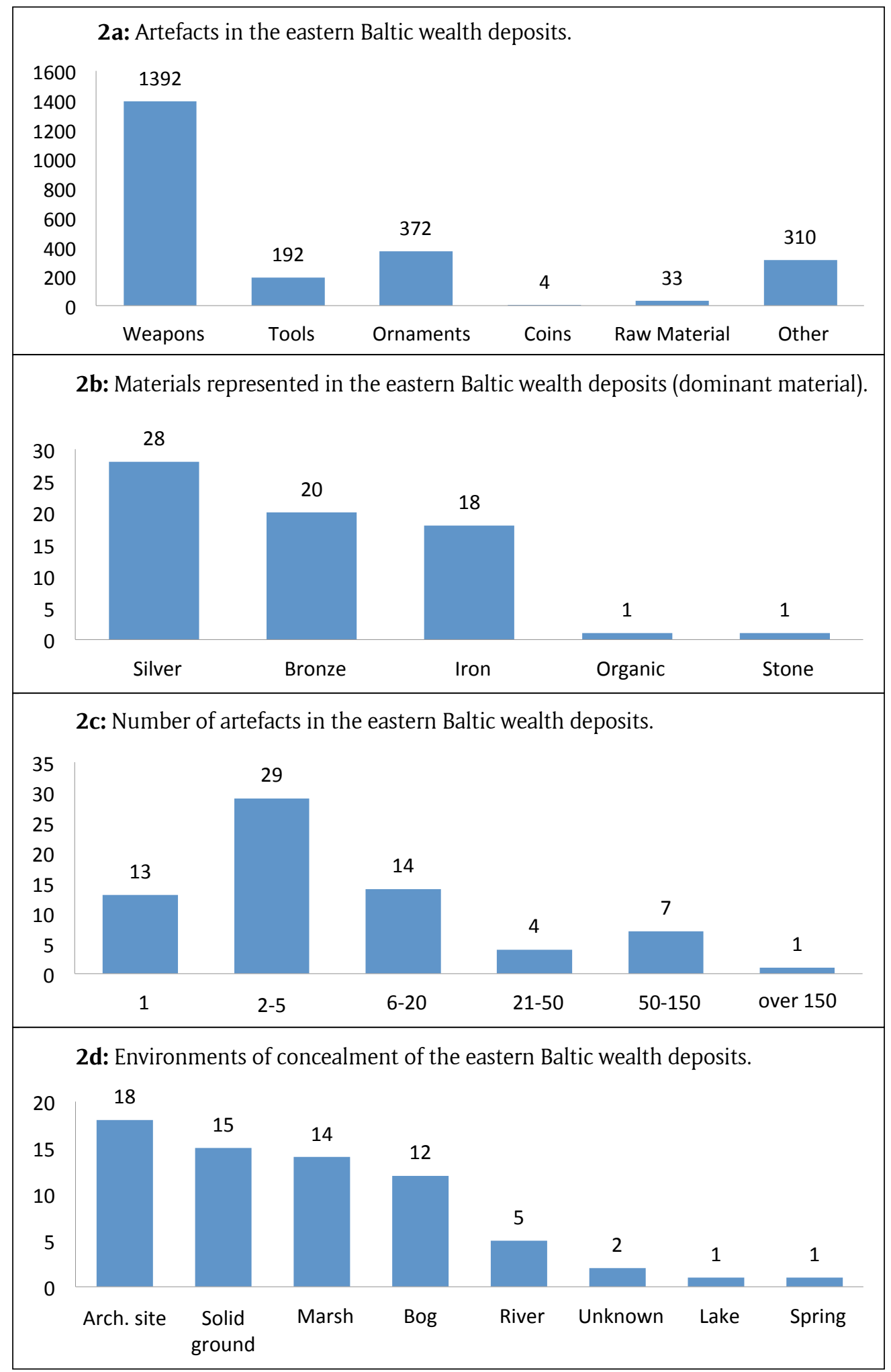




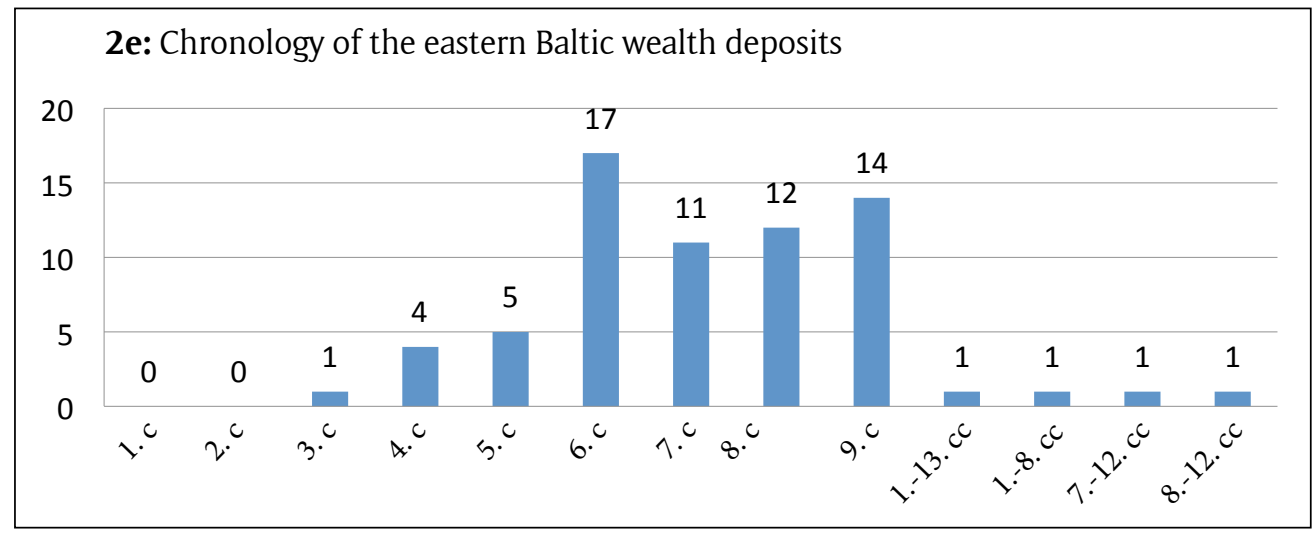

Fig. 2(a-e): The main characteristics of the eastern Baltic 1.-9. century AD wealth deposits.

vides an example of how the source material influences broader theoretical and methodological concepts and how a set of archaeological data might question the usage of traditional terms and concepts and provide a basis for inventing new and, hopefully, more suitable ones. The latter will be supported by a case study of the 1.-9. century AD Estonian wealth depositional material.

\section{Introduction of the Source Material}

My $\mathrm{PhD}$ research concentrates on different practices of wealth deposition in the eastern Baltic during the period of $1 .-9$. century $A D$ (figure 1). These centuries cover the periods of Roman Iron Age (1.-(mid-)5. century AD) and Middle Iron Age ((mid-)5.-9. century AD) in the eastern Baltic chronology of the Iron Age. My source material comes from the three Baltic countries (i.e. Estonia, Latvia and Lithuania).

The aim of the study is to analyse how and why depositional practices change in time and space. In particular, the study asks which artefacts are deposited, where and how are artefacts deposited and what are the broader social processes that influence and might be the reasons for artefact deposition and the specific materialities of that practice? The hypothesis is that there were different reasons for, relations to, ideas about and therefore practices of hiding artefacts, and that these are expressed through different material contexts. By context I mean here a range of the material characteristics of a deposit: artefacts; artefact placement in the deposit; environment of concealment; location of the deposit in the cultural landscape and its relation to other archaeological sites; chronology and geographical distribution of different deposits. These general questions prescribe that the source material cannot be limited by preconditioned categories or interpretations of the deposits. It is necessary to include all the source material that can be distinguished as intentionally concealed assemblages of artefact(s) within the full spectrum of archaeological material. Only that kind of approach makes it possible to analyse different depositional practices, track changes in time and space as well as set them in their broader social context.

The total number of finds from the eastern Baltic is around one hundred (mainly according to Bliujienè 2010; Ducmane and Ozolina 2009; Jaanits et al. 1982; LAA III 1977; Michelbertas 2001; Oras 2009, 2010; Urtāns 1964, 1977). However, in the following brief overview coin finds are only included if they have been found together with any other artefact type. The total number of Roman coins found as separate deposits in the eastern Baltic reaches 700, although some of the hoards are uncertain. Deposits with insufficient information about either the situation of finding or the artefacts themselves have been excluded, leaving the total number of presented finds just under 70 (see figure 1). 
As can be seen in the graphs (figure 2), my primary data covers a variety of materials and artefact groups. There are weapons, tools, ornaments and coins (figure 2a) made of precious metal, iron and bronze. Organic and also mineral materials are represented (figure $2 \mathrm{~b}$ ). The number of hidden objects in each deposit varies from one to over a thousand (figure 2c). The environments of concealment include examples of various watery contexts, solid ground, and archaeological sites (figure 2d). In addition, it can be shown that the chronology of artefacts in a single group does not always refer to a single event of hiding, but that in some cases artefacts can be dated to centuries quite remote from each other, possibly indicating that the same area has been repeatedly used for depositional practices over a long period of time (figure 2e). All these characteristics made me think more thoroughly about the choice of an umbrella-term for my source material, especially when I began testing and analysing those which have been traditionally used.

\section{Previously Used Terms}

I have decided for clarity to group the variety of terms that are used for the deposits of artefacts into smaller categories. The first of these term-groups I call 'interpretationally loaded': those where the term and its traditional usage dictate the nature of the material and its interpretational characteristics. The second group, which I have called 'neutral' terms, is more abstract and less restrictive.

\section{Interpretationally loaded terms}

Without doubt, the most popular and widely used terms for the deposits of artefacts are 'hoard' and 'treasure'. The Oxford English Dictionary defines a hoard as "An accumulation or collection of anything valuable hidden away or laid by for preservation or future use; a stock, store, esp. of money; a treasure" whereas a treasure is "Wealth or riches stored or accumulated, esp. in the form of precious metals; gold or silver coin; hence in general, money, riches, wealth".
The use of those terms in England is closely related to the $12^{\text {th }}$ century law of Treasure Trove which was supposed to ensure that the Crown acquired newly discovered valuables that were without legal ownership (Millett 1994: 102; for legal discussions see Cookson 1992; Hammond 1982; Sparrow 1982). Accordingly, hoards and treasures are defined as valuables, often consisting of means of payment and/or precious metal, meant to be retrieved, but which for some reason remained ownerless in the ground. This leads to an implication that a hoard or treasure is related to the safe-keeping of valuables for economic reasons.

These traditional and historically developed concepts carry with them issues for their use in archaeological study. First of all, they tend to limit the source material to an assemblage of artefacts, excluding single object finds. Secondly, these ideas imply that precious metal objects, most often coins, should form the basis of a treasure. Although not explicitly expressed in the case of hoards, the emphasis on money to some extent implies precious metal as well. Finally, the interpretation of these categories relates to economically-aimed concealment, which sets them apart from the other interpretationally loaded groups of terms: i.e. votive or ritual deposits (see below).

These problems have been noticed by archaeologists before. The number of artefacts concealed might be important for dismissing the possibility of confusing intentionally hidden and accidentally lost objects. Therefore some are certain that a hoard must consist of more than a single item (Chapman 2000: 112; Johns 1996: 1; Verlaeckt 2000: 194). On the other hand, if it comes to the question of value, some single objects might be worth more than a collection of others. Limitation by number of artefacts is not, therefore, always an appropriate approach (Aitchison 1988: 271; Geißlinger 1984: 321; Hingley 2006: 215-216).

The notion of precious metal as a proxy for value is also easily questioned. Precious 
metal, especially in the form of coins, might be valuable for certain societies, but is not necessarily a universally applicable standard. In a Stone Age context, for instance, very different forms and materials of deposited items are the norm (Bradley 1988: 250; see examples in Hamon and Quilliec (eds.) 2008). Predominantly precious metal finds from the Roman period can also be compared with the preceding and following periods that include non-precious metal artefacts that were probably regarded as valuable and thus hoarded (Hingley 2006; Johns 1996: 1; Millett 1994: 104; Verlaeckt 2000: 194). In the case of the eastern Baltic Iron Age, especially during the first half of the $1^{\text {st }}$ millennium $A D$, most of the deposited items are bronze ornaments (see below). Precious metal is very rare in general, both in burials and other contexts (see e.g. Lang 2007a). I doubt that no concept of value was attached to those objects just because they were made of non-precious metals.

Finally, for a long time there has been a tendency towards separating hoards and treasures relating to economic and utilitarian life from others: votives, ritual deposits, offerings. Traditionally the distinction was made on the basis of the environment of concealment. The finds from water bodies were treated and studied separately from economic hoards (e.g. Bradley 1988: 249; see also Van Rossenberg 2003: 157). As a result, for a long time two separate groups of artefact deposit were set in opposition to each other: pragmatic, utilitarian, profane, secular and symbolic on one hand; special, ritual, religious, sacred on the other (see e.g. Bradley 1990; Geißlinger 1984: 322; Gerrard 2009: 179; Hårdh 1996: 131-132; Hedeager 1992: 33-36; Hingley 2006: 214; Levy 1982; Reece 1988: 264).

This brings us to a discussion of the second interpretationally loaded group of terms 'ritual/votive deposits or sacrifices/offerings' (see e.g. Bradley 1990; Hedeager 1999; Hines 1989; Ilkjær 2002; Jørgensen et al. (eds.) 2003; Levy 1982; Osborne 2004; Richards and Thomas 1984; Stjernquist 1997; Yates and Bradley 2010). These deposits are interpreted as the material results of religious or ritual-related activities. Often they are characterised as consisting of somehow special objects that are meant to be non-retrievable; watery or religiously interpreted sites are regarded as the most suitable environments of concealment for such assemblages.

All of these interpretationally loaded terms derive from an idea that there must have been two clearly separate reasons for depositing artefacts and that they can be grouped initially according to material contexts. However, this two-fold opposition is quite problematic when put it into practice. For instance, it is not always the case that religious or ritual-related actions include only special and distinguished objects. The possibility cannot be excluded that mundane and ordinary items might be used in those practices as well (see e.g. Bradley 2003, 2005; Johns 1996: 9; Osborne 2004: 2). Moreover, a special environment of concealment such as a temple or water does not always indicate the sacred nature of the assemblage of artefacts. Valuables might be in the water for safe-keeping (see e.g. Geißlinger 1984: 322323; Johns 1994: 114; Randsborg 2002) or in temples for future retrieval (see e.g. Johns 1994: 111-114, 1996: 9-10). The question of unfortunate loss of items in watery conditions as opposed to acknowledged practice have been discussed as well (see e.g. Samson 2006). Therefore it is almost impossible to create a universal check-list for ritual or religious deposits (or even a hoard), because there are no such cross-cultural criteria. I am not trying to deny that there were different reasons for concealing artefacts, religious or ritual-related reasons among them. However, this kind of distinction cannot be a starting point for an analysis of the research material, but should, rather, grow out from the overall set of data as an end-result or interpretation-if at all.

The problems associated with dividing the archaeological material into traditional con- 
cepts of 'hoard'/'treasure' vs. 'votive/ritual deposits' have been identified before (see e.g. Bradley 1987, 1988, 2003; Brück 1999; Hamon and Quilliec 2008; Manning 1972: 238-239; Verlaeckt 2000: 194) and the initial division of deposits into either-or-groups has become debatable. The same applies to the interpretation of whether an object was meant to be retrieved or remain in place, sacred and untouched. In England this was part of the reason for the replacement of Treasure Trove by the new Treasure Act after $1997^{2}$, amended in $2002^{3}$. Now the law covers assemblages of different prehistoric metal objects and the distinction of retrievable $v s$. non-retrievable is no longer a conclusive point of reference. However, the traditional usage and understanding of terms takes time to change, and therefore the continued use of the same terms might still confuse both authors and audience.

\section{Neutral terms}

The second larger group of terms I have named as 'neutral', because they are more abstract and less interpretative. They all use the word 'deposit' (see also Joyce and Pollard 2010, 294 and the literature cited; Aitchison 1988: 271), to which different adjectives structured, special, selective (see below) are added.

The term 'structured deposits' was first introduced by Richards and Thomas (1984) in the context of Neolithic material from Durrington Walls, Wessex. They were referring to some rule-bound and repeated depositional activities that occurred in patterned and structured archaeological assemblages. Quite similar is the term 'selective deposits' used by Needham (1988) about the finds of Bronze Age metalwork in Britain. He was able to show that there occurs a certain degree of selection in the types of artefacts and the places of their concealment, marking a distinction between objects hidden in funerary contexts and those in other deposits. Similar concepts around the selection of artefacts and their environments of con- cealment and how these choices relate to the aims of the depositors have been demonstrated in prehistoric material from the Netherlands' (Fontijn 2002, 2008; Wentink and van Gijn 2008). Finally, the term 'special deposit' has been mainly used in the study of the Iron Age or even later periods (Clarke 1997; Cunliffe 1992; Hamerow 2006; Hill 1995). It refers to specially treated and intentionally hidden assemblages of artefacts. The concept of 'special' emerges in relation to extraordinary objects and/or their handling and placement, or in an unusual environment of concealment.

All these terms - 'structured', 'special' or 'selective' deposits - share common features. They are distinguished due to their somehow extraordinary or special character that can be identified in the archaeological record as a result of structuring, repetition, intentional selection or patterning. Their extraordinary characteristics are traced either in unusual artefacts, their special treatment and placement in the deposit, or place of concealment. In addition, reading all the previously cited works it becomes clear that these concepts have been established in order to distinguish ritual, especially ritual deposits, within a broader archaeological context. Thus the idea that ritual deposits can and must be distinguished from the others remains.

Even if less preconditioned and abstract in their essence, these terms too turn out to be problematic in the wider context. First, the notion of structured and selective deposits cannot be a definitional help, because probably all depositional activities, from burials to rubbish decay, are to some extent structured and selective (see e.g. Hill 1995: 96; Moore 1982; Pollard 2001: 316, 2008: 43), patterned and repeated. But, if it comes to patterns and repeated practices, what about the unpatterned and non-repeated: the unique and unparalleled finds? Should one leave those aside or identify them as 'special'? How should 'special' be defined and distinguished in a prehistoric context anyway (Brudenell and Cooper 2008: 24; Mills and Walker 2008: 
21; Pollard 2008: 43)? And what are the criteria for arguing for clear selection or random choice?

Finally, it remains an issue that all these terms are aimed at studying past ritual. Therefore, at least some of them are distinguished from and, to some extent, even opposed to other finds - either ordinary or absolutely unique depositional practices. This leaves us still with separated depositional groups: one relating to religion and ritual, the other with utilitarian and economic intentions or just reflecting weird activities. However, in more recent studies there is a tendency towards analysing depositional practices and formations in general, without an initial goal of separating and opposing them in the first place (Berggren 2006, 303; Berggren and Stutz 2010; Bradley 2003, 2005; Chapman 2000: 130; Joyce 2008: 27-28; Joyce and Pollard 2010; Mills and Walker 2008; Morris and Jervis 2011; Pollard 1995: 137; Van Rossenberg 2003).

\section{Need for a New Term: Wealth Deposit}

Comparing these traditional terms to my own source material in the context of my research questions reveals a theoretical gap; an incommensurability of previous concepts with my own data. The eastern Baltic material of separate artefact deposits covers such a variety of contexts that as a whole it does not fit any of these terms and definitions introduced above. Additionally, if my aim is to discuss practices of, and changes in, artefact deposition, I need to examine the broadest data selection possible. Therefore, I cannot limit my data set by restricting it on the basis of production material, environment of concealment or number of artefacts. Approaching the material with preconditioned concepts such as utilitarian or economically oriented hoards $v s$. ritual deposits and starting with the intention of searching for only these two interpretational groups would not take me further in the analysis of the varying practices and cultural backgrounds associated with hiding artefacts. On the contrary, answering my research problem requires variation in the source data characterised by a diversity of material contexts. Therefore, terms such as 'hoard', 'treasure' and 'ritual/ votive deposits' do not fit with the data and questions at all.

More neutral terms such as 'selective/structured/special' have their own disadvantages (see above). Although the concept of 'selective deposits' is perhaps the least problematic, it is not the best solution for my current research, because my study does not include an in-depth analysis of artefacts from all other archaeological sites. Besides this, such terms are encoded with an idea of patterns and repetition in the source material which might easily exclude exceptions and deposits with unparalleled characteristics. Although I am aiming to find broad patterns of depositional practices, there are still some single examples which raise questions about the way that deposited material is categorized. For instance, should one concentrate on silver neck-rings as a single phenomenon, or include all neck-rings or perhaps even ornaments in general under the same heading? I am arguing that emerging patterns might actually be found in a continuous dialogue between different deposits, their contextual characteristics, categorisations and the acceptable degree of connection between them.

Taking all this into account, there was a need for me to come up with a more suitable term for naming and defining my research material. The result is the term 'wealth deposit' by which I refer to one or more object/s of value that is/are hidden deliberately as an intended and separate deposition of specifically chosen object(s) into a specifically chosen place in a specific manner. It refers primarily to an act of depositing which must be intentional, and acknowledged. It therefore involves choice: of objects, the environment of deposition and how the objects are placed. The analysis of these criteria should enable the separation of wealth deposits from other, function- 
ally and meaningfully different, depositional practices such as for instance burials, rubbish decay, loss of items etc. It also allows for an analysis of different practices of deposition without any prior need to divide them into interpretational groups.

\section{Question of Value}

The formulation 'objects of value' is perhaps the most problematic part of the definition and needs further elaboration. Value can be both universally accepted and understood, but it can also have subjective connotations - it can be created through certain personal or culture-specific contexts. Value is both an emic and an etic concept, which therefore derives from cultural and cross-cultural concepts of valuables (Renfrew 1986: 146).

Some objects have a tendency to be valuable universally and cross-culturally. Most often they are characterised as rare, durable and attractive, often used as prestige and symbolic items (Haselgrove 1982; Lesure 1999: 33; Parker Pearson 1999: 79; Renfrew 1986: 148-149). Precious metal objects in general can be viewed in this way. Value can be universally added and understood through production efforts: the higher the labour in-put for material production, its creation into an artefact, its decoration, perhaps even its size and specific production techniques, the more valuable the object itself (Arnold 1980: 108; Lesure 1999: 27-28, 30). In the context of the eastern Baltic in the Iron Age, metal artefacts most certainly held value because no precious metal is naturally available in these areas and the production of iron from bog ore was a labour-intensive specialist activity (see e.g. Peets 2003; see also Budd and Taylor 1995; Haselgrove and Wigg-Wolf 2005: 11-12; Hedeager 2011: 139-144 and the literature cited; Hingley 2006: 217; Rowlands 1971; Walker 1995: 77 and the literature cited).

However, value is not only a matter of economic and measurable characteristics alone, but relates to a specific society and its own social contexts (Appadurai 1986: 23; Dav- enport 1986: 108; Lucero 2008: 190; Miller 2001: 114; Mills 2004: 238; Myers 2001: 12; Renfrew 1986: 159). Symbolic values might be created in object biographies, their circulation, and ownership-relations (see e.g. Hamon and Quilliec 2008: 2; Härke 1997: 145; Haselgrove 1982: 82; Hingley 2006: 234; Lesure 1999: 25; Parker Pearson 1999: 94; Renfrew 1986: 160; Thomas 1999: 73). Value might be related to individual perception and sentimental connections (Lillios 1999; Renfrew 1986: 158-159) or to the symbols and signs of group identity (Davenport 1986; Kopytoff 1986: 73-74; Miller 2001: 108; Mills 2004: 239-240; Myers 2001: 9, 58; Weiner 1992). Value might also be given in practice itself, for instance in the act of hiding (Hamon and Quilliec 2008; Johns 1996: 2; Millett 1994: 99-100). Objects invested with such values might look like nothing special (see e.g. Bradley 1988: 250; Hamerow 2006: 17-19; Thomas 1999; Weiner 1992). Therefore, value is also a question of socially situated relations, practices and histories $-\mathrm{a}$ matter of specific and contemporary social context - and therefore the value of objects might even change in time and space (Keane 2001: 70; Myers 2001: 7, 9-10, 55; Parker Pearson 1999: 84; Pauketat and Alt 2004: 794; Renfrew 1986: 162).

If we are not to assume universal and crosscultural values, the identification of objects of value must be sought in the material characteristics of the deposit considered against the background of its cultural context (Davenport 1986: 106-107; Kopytoff 1986: 73-74; Lesure 1999: 28, 32; Myers 2001: 56). The object's value for past people can be traced by analysing the way and locales in which artefacts have been treated and placed in comparison with other material culture. Valuables were most probably used selectively, not anywhere or in any way (Lesure 1999: 33). Therefore, specially treated, singularised, decommodified or recognisably combined sets of otherwise ordinary objects and/or hiding locales hint that they might have carried a special meaning and value for 
the people who concealed them. In the eastern Baltic, unique forms of artefacts that are unknown from other archaeological sites, certain amounts or combinations of objects and special natural or man-made sites can hint that the objects had a special value and meaning. However, such evaluations are most certainly easier to discover through certain repeated depositional patterns that are expressed in contextual characteristics (Lesure 1999: 32; Pollard 2001; Walker 1995: 72-73, 79).

I would finally argue that the use of the term 'wealth deposit' as I have defined it helps to overcome at least some of the problems with the traditional terms, and also think more open-mindedly about the object's value itself. It enables one to include and compare considerably broader source material, regardless of production materials, numbers of artefacts, or environment of concealment and, most importantly, without any preconditioned and interpretationally loaded starting points. Wealth deposit is rather like a general umbrella term for different artefact deposits that is open for any kind of final interpretations. The concept of wealth and value allows the inclusion of both universally accepted and culture-specific precious items. It also emphasises the importance of depositional contexts - material and social - because value is assigned and therefore recognisable for a researcher through those contexts. More importantly for my own research, contexts also help in comparing different depositional practices, their changes and developments in time and space.

\section{From Theory to Practice: A Case Study from Estonia}

To exemplify how the concept of wealth deposit can be useful in practice I will briefly discuss a case study from Estonian material. This is not intended to be an exhaustive analysis of the practices of wealth depositing in this region at the relevant time period. Rather the aim here is to show how and why it is possible to benefit from the concept of wealth deposit as outlined above.

The list of Estonian 1.-9. century AD wealth depositional material consists of 28 finds. However, not all the possible candidates - separate artefact deposits - have been included. First, it is necessary to ensure that the deposits under discussion must, or are highly likely to, derive from intentional and separate artefact deposits other than from any essentially and functionally different past practices (burials, rubbish decay, lost items etc.). This information derives from a detailed analysis of the environment of concealment and related artefactual material of the deposit. For instance, questions such as associated (human) bones, settlement activity areas, special arrangements in the surroundings of the deposit (built structures, markers above ground), physical environment (dry land, water bodies, marshes), and placement of artefact(s) should be mentioned in this context. If there are cases when the circumstances of the discovery are unclear, the findspot unknown or exact content of the finds unclear, then such deposits are not included in the following discussion. In addition, all the findspots have been visited in order to inspect any relevant additional data about the circumstances and the environment of concealment. This kind of information, based on the analysis of archive materials and historic maps, objects themselves and the surroundings of the findspots, make it possible to identify potential intentionally and separately concealed objects-i.e., 'wealth deposits' (see table 1, figures 3 and 4).

In the case of Estonian material, the first thing that strikes the eye is that during the first half of the $1^{\text {st }}$ millennium $A D$ most of such finds consist of bronze items. Altogether, eight out of ten deposits from $4^{\text {th }}$ to early $6^{\text {th }}$ century consist either solely or dominantly of bronze ornaments, mainly neck-rings and bracelets. This cannot be a random coincidence and must imply a certain acknowledged depositional choice and practice. There are only two finds in which silver as a produc- 


\begin{tabular}{|c|c|c|c|c|c|c|c|c|c|c|c|c|c|c|}
\hline 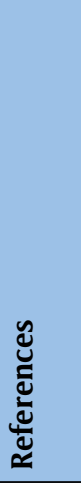 & 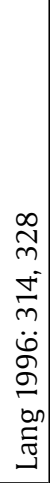 & 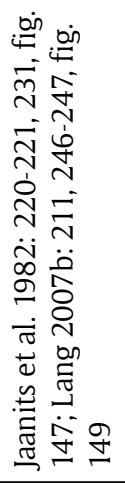 & 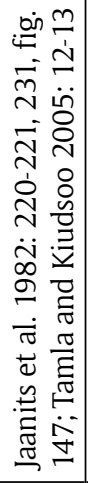 & 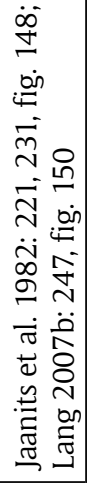 & 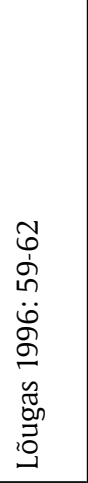 & 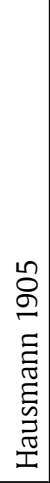 & 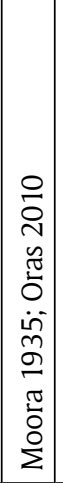 & 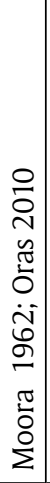 & 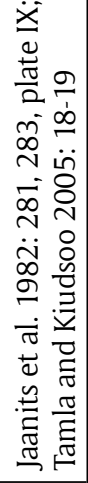 & 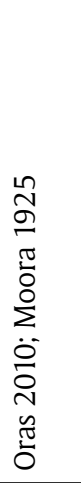 & 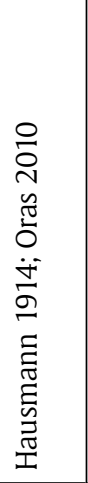 & 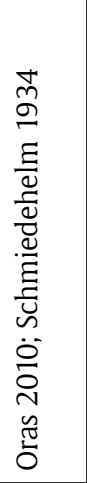 & 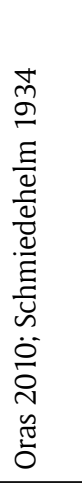 & 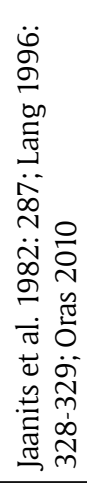 \\
\hline 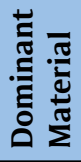 & 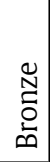 & $\begin{array}{l}\stackrel{̃}{N} \\
\stackrel{0}{0}\end{array}$ & 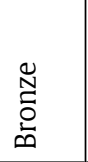 & $\begin{array}{l}\stackrel{N}{N} \\
\stackrel{0}{0}\end{array}$ & $\stackrel{\bar{\varpi}}{\bar{n}}$ & 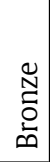 & $\mid \begin{array}{c}\stackrel{N}{N} \\
0 \\
0 \\
\stackrel{0}{0}\end{array}$ & 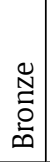 & $\begin{array}{l}\tilde{N} \\
\text { D. } \\
\text { ص. }\end{array}$ & $\stackrel{\bar{\varpi}}{\bar{\varpi}}$ & $\stackrel{\bar{\varpi}}{\grave{n}}$ & $\stackrel{\bar{\varpi}}{\bar{n}}$ & $\stackrel{\bar{\varpi}}{\bar{\varpi}}$ & $\stackrel{\bar{\varpi}}{\stackrel{\bar{n}}{\bar{n}}}$ \\
\hline 离 & & & & & & - & & - & & & - & & & \\
\hline 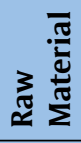 & & & & & & $\nabla$ & & & & & & & & \\
\hline ฮै & & & & & & & & & & & & & & \\
\hline 宅 & in & $\sim$ & $\underline{\sigma}$ & $\sim$ & $m$ & & $F$ & 이 & - & $\beth$ & $\stackrel{\sim}{\sim}$ & $m$ & $\stackrel{\sim}{\sim}$ & in \\
\hline$\frac{n}{\circ}$ & & & & & & & & & & & & & & \\
\hline 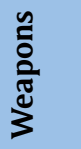 & & & & & & & & & & & & & & \\
\hline 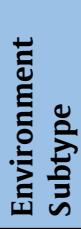 & 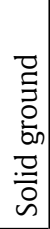 & 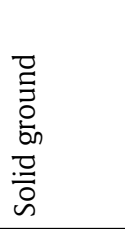 & 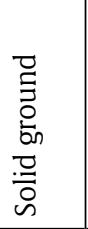 & 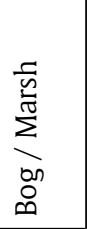 & 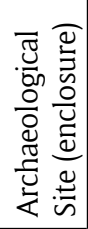 & 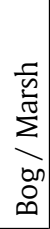 & 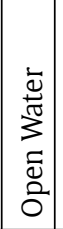 & 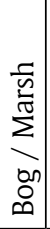 & 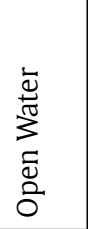 & 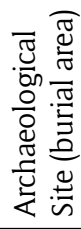 & 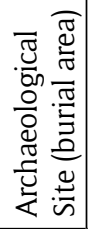 & 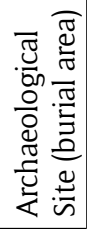 & 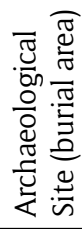 & 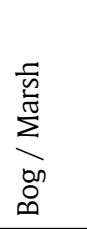 \\
\hline 胥 & $\nabla$ & $\nabla$ & $\nabla$ & $\stackrel{n}{\perp}$ & $\stackrel{\dot{n}}{\dot{m}}$ & $\stackrel{\stackrel{n}{n}}{\sim}$ & 6 & 6 & $\begin{array}{l}\text { bे } \\
\text { in }\end{array}$ & 6 & 6 & 6 & 6 & 6 \\
\hline 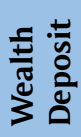 & 刍 & : & 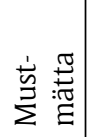 & $\begin{array}{l}\frac{\pi}{3} \\
\frac{\sqrt{n}}{\tilde{n}} \\
\frac{0}{2}\end{array}$ & $\begin{array}{l}\overline{\bar{\pi}} \\
\underline{\widetilde{\pi}}\end{array}$ & 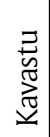 & $\stackrel{\overline{\mathfrak{n}}}{\vdots}$ & $\begin{array}{l}\frac{\pi}{0} \\
\ddot{d} \\
\approx\end{array}$ & 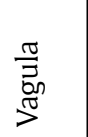 & 离 & $\begin{array}{l}\frac{\pi}{\vec{\sigma}} \\
\frac{\vec{\pi}}{\underline{T}}\end{array}$ & 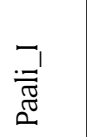 & $\begin{array}{l}= \\
=\bar{\pi} \\
\bar{\sigma} \\
\bar{v}\end{array}$ & $\stackrel{\Xi}{\Xi}$ \\
\hline
\end{tabular}




\begin{tabular}{|c|c|c|c|c|c|c|c|c|c|c|c|c|c|c|c|}
\hline 怤 & 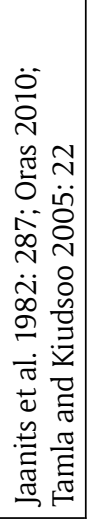 & 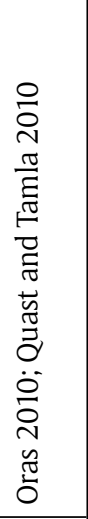 & 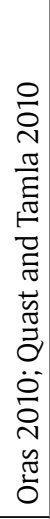 & 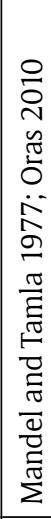 & 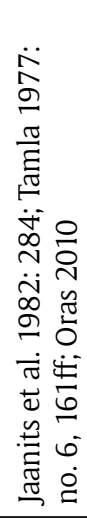 & 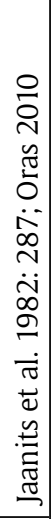 & 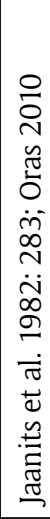 & 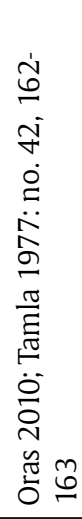 & 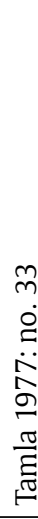 & 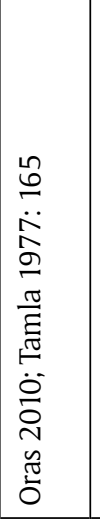 & 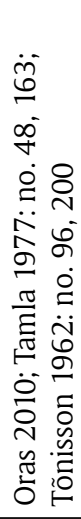 & 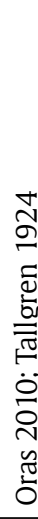 & 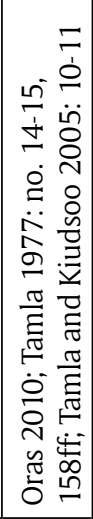 & 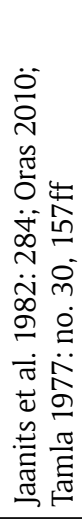 & 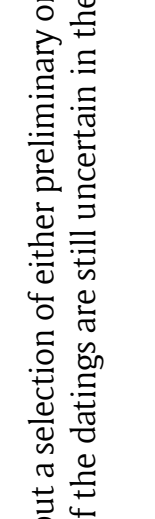 \\
\hline 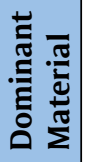 & $\stackrel{\bar{\varpi}}{\stackrel{\varpi}{n}}$ & $\stackrel{\bar{\Phi}}{\stackrel{\bar{n}}{\bar{n}}}$ & 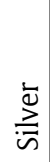 & Бే & ఏ్ & 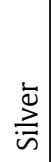 & 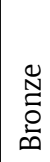 & $\stackrel{\bar{\varpi}}{\bar{n}}$ & 오 & 읍 & $\stackrel{\bar{\varpi}}{\bar{n}}$ & 을 & $\stackrel{\Xi}{0}$ & 동 & 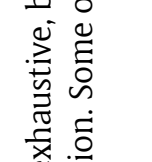 \\
\hline 离 & & - & - & & & & & & & - & & $m$ & $m$ & 6 & 总 \\
\hline $3 \stackrel{\substack{\frac{\pi}{2} \\
\frac{\pi}{\pi}}}{\stackrel{\pi}{\pi}}$ & & & & & & & & & & & & & & & 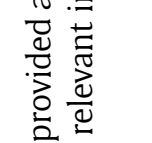 \\
\hline. & & & & & & & & & & $\tilde{=}$ & & & & & 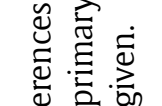 \\
\hline 窝 & $=$ & & & & & $m$ & $m$ & - & & & $m$ & $\tilde{m}$ & & & 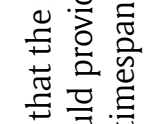 \\
\hline$\stackrel{n}{\circ}$ & & & & & $\infty$ & & - & & & - & & - & $\stackrel{\infty}{\sim}$ & $N$ & 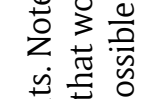 \\
\hline 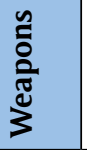 & & & & 6 & $\sigma$ & & & & $N$ & $\nabla$ & & $\stackrel{\mathrm{m}}{\mathrm{m}}$ & $\widehat{\sigma}$ & $\stackrel{\llcorner}{\sim}$ & 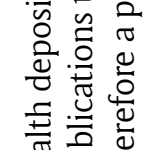 \\
\hline 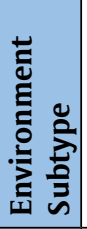 & 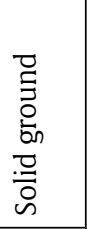 & 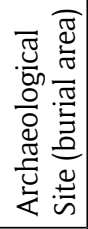 & 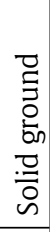 & $\begin{array}{l}\overline{ \pm} \\
\frac{\pi}{3} \\
\overline{0} \\
0 \\
0\end{array}$ & 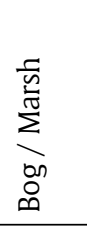 & 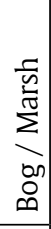 & 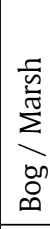 & 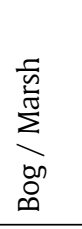 & $\begin{array}{l}\frac{5}{\pi} \\
3 \\
0 \\
0 \\
0\end{array}$ & 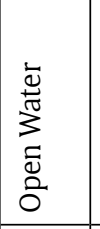 & 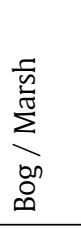 & 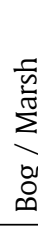 & 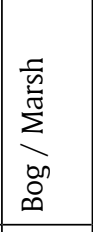 & 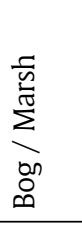 & 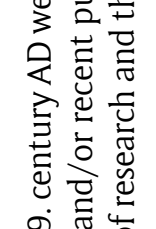 \\
\hline 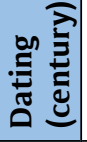 & 6 & 6 & 6 & $\Lambda$ & 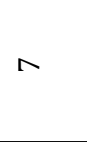 & $\infty$ & $\infty$ & $\infty$ & $\sigma$ & $\frac{\circ}{\sigma}$ & $\frac{\circ}{\sigma}$ & $\frac{\circ}{\circ}$ & $\stackrel{m}{\stackrel{1}{\prime}}$ & $\stackrel{\infty}{\stackrel{\infty}{\leftarrow}}$ & 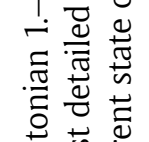 \\
\hline 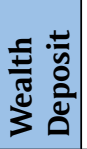 & $\stackrel{\sqrt[0]{0}}{>}$ & : & 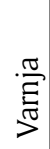 & 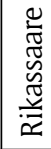 & 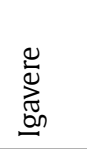 & 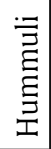 & $\begin{array}{l}= \\
\underline{\underline{\sigma}} \\
\Xi \\
\underline{\Xi}\end{array}$ & $\begin{array}{l}\overrightarrow{\overline{0}} \\
\stackrel{\pi}{\pi} \\
z\end{array}$ & $\begin{array}{l}\frac{\tilde{J}}{\pi} \\
\frac{\pi}{\tilde{J}}\end{array}$ & 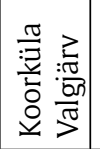 & $\overrightarrow{\tilde{8}}$ & $\frac{\pi}{\frac{\pi}{3}}$ & $\frac{\Xi}{\Xi \Xi}$ & 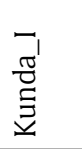 & 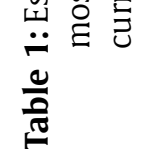 \\
\hline
\end{tabular}




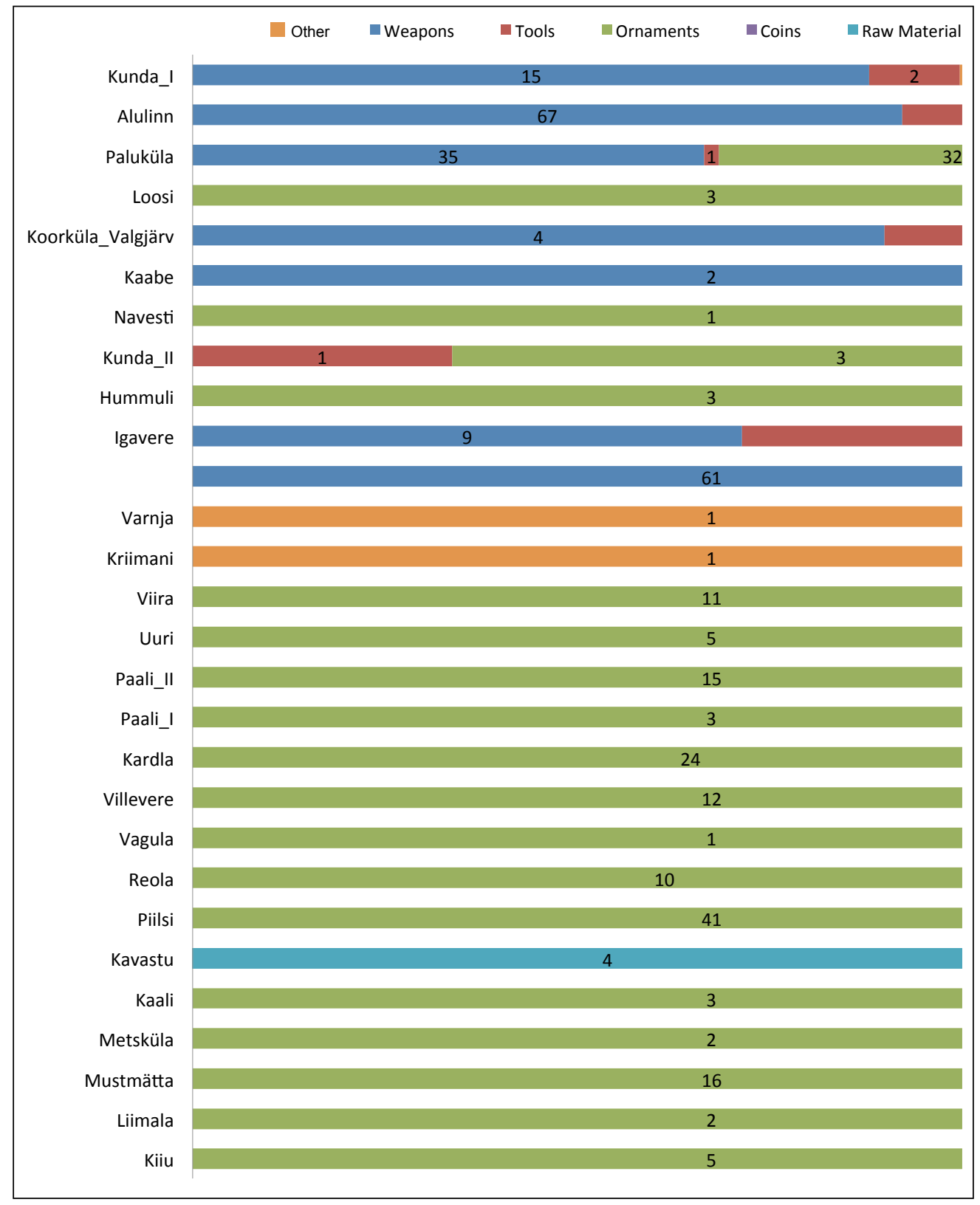

Fig. 3: Artefact types and their numbers of Estonian 1.-9. century AD wealth deposits. Data is represented in chronological order.

tion material is dominant. However, in terms of concealed object types, most of these finds share a common character. They consist of bronze ornaments, namely, neck-rings in earlier centuries, and arm rings and other bronze rings in later ones. In the given case it would be most unfortunate to exclude the majority of such deposits and dismiss the value of such items just because they do not include precious metal objects. This is especially problematic when asking broader questions about the scale of depositional practices-e.g. when 


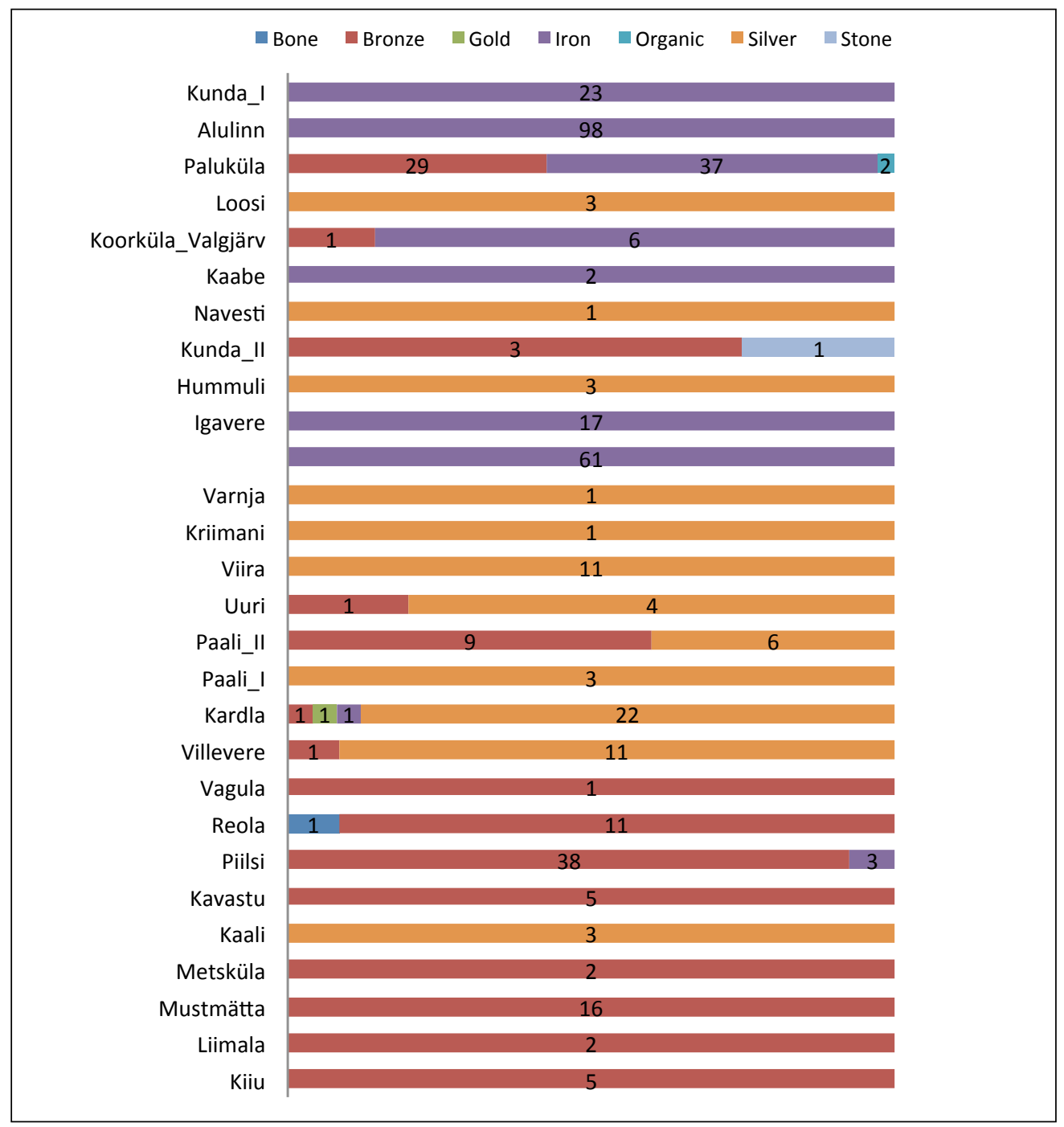

Fig. 4: Materials represented in Estonian 1.-9. century AD wealth deposits. Data is represented in chronological order.

do ornament deposits seem to dominate in the depositional material and what might be the broader cultural background or reason for that? For example, in reference to the latter, we might compare the deposits of bronze and silver ornaments (see figure 4 ) in a long-term perspective, asking about the continuity and discontinuity of this specific depositional tradition.

This brings us to the question of second untraditional material and subtype of objects - weapons and tools as separate deposits. There is a clear distinction between the choices of deposited artefacts in Estonian 1.-9. century AD material. The separation seems to follow a distinction between deposits of ornaments (either bronze or silver) and weapons-tools (iron objects in general). More importantly, to some extent these traditions alternate in temporal terms: from the $7^{\text {th }}$ century onwards weapon and tool deposits show an increase whereas ornament 


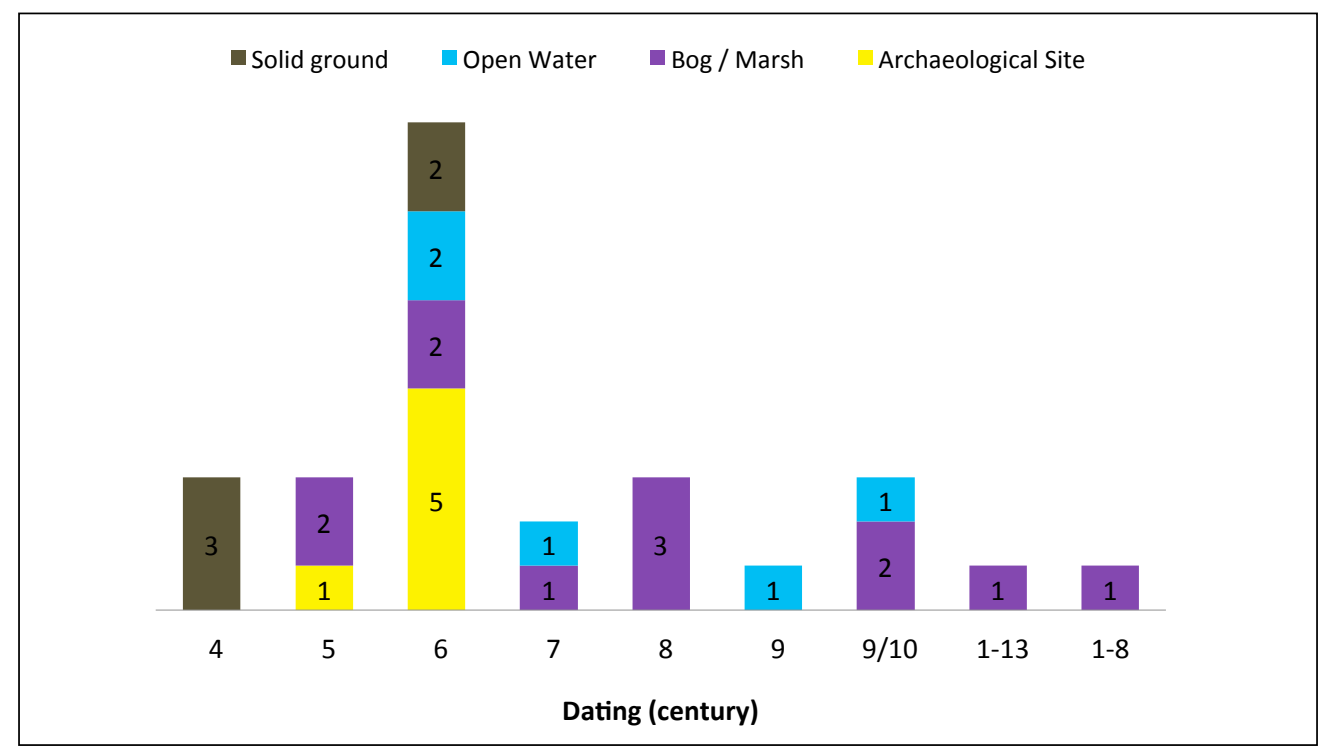

Fig. 5: Environments of concealment of Estonian 1.-9. century AD wealth deposits.

deposits decrease at the same time, starting to emerge again at the turn of the $9^{\text {th }}$ century but this time in much smaller quantities (1-3 silver neck-rings) (see figures 3 and 4). In addition, looking at the long-term use of some sites it is striking that some are consistently dominated by the deposits of iron objects, be it tools or weapons, with very little or no ornament deposits at all. And again, without such widely based comparisons and by excluding iron artefact deposits it would be easy to miss out some quite interesting depositional patterns and their distribution in space and time.

The problem of distinguishing single objects as separate artefact finds as opposed to accidental loss needs some attention too. Although agreeing that in general it is rather problematic to make a distinction between intentional deposit and lost item I would argue that again the broader scale of analysed data can be helpful here. First of all, in some lucky circumstances it is possible to actually see from the environment of concealment that the deposit must have been an acknowledged act. Such examples are the two Byzantine silver vessels from Estonia one discovered under a stone, the other from the heap of stones of an old stone grave (see Oras 2009, p. 38, 44, nos 6, 18; Oras 2010, nos 10, 11; Quast and Tamla 2010). Both the environment of concealment and the measurements of the artefact testify that accidental loss is almost impossible. Slightly similar can be an argumentation for including a single silver neck-ring in the current overview. The reason being that such neck-rings have been discovered in other contemporary deposits, consisting of this kind of artefact type solely. In addition, it would have been easy and feasible to retrieve such a large object from dry land.. Thus, it is likely that again we are looking at intentional and acknowledged depositional activity.

Finally, the general overview about the environments of concealment should be outlined. As can be seen from a simple graph (figure 5 and table 1), there are no distinct temporal patterns in this regard at first glance. However, if one takes a closer look at the findspots and compares them with deposited items, some clearer tendencies can be followed. The simplest is to notice that iron objects - weapons and tools belong together with various watery conditions. Bronze rings and precious metal orna- 
ment deposits from the first half of the $1^{\text {st }}$ millennium $\mathrm{AD}$ come from the solid ground, whereas the later ones show a connection to nearby burial areas. At the same time, ornament deposits from the second half of the $1^{\text {st }}$ millennium $\mathrm{AD}$ seem to fall into similar environmental conditions with the deposits of slightly earlier or contemporaneous iron objects. These are some of the possible instances of when and why it is fruitful to analyse the data from different environments and findspots together.

These preliminary examples help to argue why the concept of wealth deposit is more suitable not only for analysing eastern Baltic data, but also for looking at practices and changes in artefact depositional traditions in broader terms. As can be seen from these few presented examples, there are quite different acknowledged practices of wealth depositing, varying in time and space and in terms of number of artefacts, environments, production material etc. That we are probably looking at socially accepted and more widely followed practices is expressed by the patterned depositional characteristics which indicate a conscious choice of objects, their material, environment and placement in the deposit. A further aim of my research, besides elaborating on those different practices of wealth depositing, is to discuss if and how they correlate with broader social developments and changes in this specific region and period. Without such a large scale overview of the whole material of intentional and separate artefact deposits, analysis of the developments and changes to those practices, as well as their relations to broader social developments, must remain tentative. Full answers to these questions, however, will be the focus of future publications.

\section{Conclusion}

I am sure that I am not alone in struggling with giving a name for this sort of research material and experiencing a situation where the traditional terms are either too specific and limited or too broad. I am not saying that one should completely dismiss the traditional terms that I have discussed above. They most certainly are appropriate in numerous cases. However, I hope I have clearly argued why this is not the case for my own study and why there sometimes seems to be a need to invent, discuss and define a new term for better understanding and coverage of the source material and research results in general. In addition, I hope that the case study and preliminary conclusions provide a good example of how and why the concept of the 'wealth deposit' can open up some new discussions about different traditions of depositing artefacts in a long-term perspective. Furthermore, this paper might also provide an example of how the terms used, source material, questions posed, theoretical and methodological concepts are and perhaps even should be in continuous dialogue with each other. It also means that terms are always open to further development as any of these denominators change. For these reasons it is important to take the usage of terms and their definitions seriously in all research.

\section{Acknowledgements}

My gratitude belongs to Dr Catherine Hills for the comments on the manuscript of this paper and to Dr David Petts for the discussion after my presentation at the $14^{\text {th }}$ IARSS conference in Durham. I would like to thank the anonymous peer-reviewers for their useful comments and feedback. This research was supported by Wolfson College (University of Cambridge), Estonian Science Foundation Grant (ETF ETF8956) 'The Materiality of Religion - religious artifacts in Estonian archaeological collections' and by the European Union through the European Regional Development Fund (Centre of Excellence CECT).

\section{Notes}

1 This paper was first presented at the 14th Annual Iron Age Research Student Seminar at Durham University, on the 27th of May 2011. 
2 Treasure Act 1996 (http://www.legislation. gov.uk/ukpga/1996/24/contents).

3 The Treasure (Designation) Order 2002 (http://www.legislation.gov.uk/uksi/ 2002/2666/contents/made).

\section{References}

Aitchison, N B 1988 'Roman wealth, native ritual: Coin hoards within and beyond Roman Britain'. World Archaeology, 20(2): 270-284, DOI: http://dx.doi.org/10.1080/ 00438243.1988.9980072

Appadurai, A 1986 'Introduction: commodities and the politics of value'. In The Social Life of Things: Commodities in Cultural Perspective. Appadurai, A (ed.). Cambridge: Cambridge University Press, 3-63.

Arnold, T M 1980 'Wealth and social structure: A matter of life and death'. In AngloSaxon Cemeteries 1979. The Fourth AngloSaxon Symposium at Oxford. Rahtz, P, Dickinson, T and Watts, L (eds.). BAR British series, 82. Oxford: B.A.R., 81-142.

Berggren, A 2006 'Archaeology and sacrifice. A discussion of interpretations'. In Old Norse Religion in Long-Term Perspectives: Origins, Changes, and Interactions: An International Conference in Lund, Sweden, June 3-7, 2004. Andrén, A, Jennbert, K and Raudvere, C (eds.). Vägar till Midgård, 8. Lund: Nordic Academic, 303-307.

Berggren, A and Stutz, L N 2010 'From spectator to critic and participant: A new role for archaeology in ritual studies'. Journal of Social Archaeology, 10(2): 171-197, DOI: http://dx.doi. org/10.1177/1469605310365039

Bliujienè, A 2010 'The bog offerings of the Balts: "I give in order to get back"' Archaeologia Baltica 14: 136-165, http://archive. minfolit.lt/arch/28501/28740.pdf.

Bradley, R 1987 'Stages in the chronological development of hoards and votive deposits'. Proceedings of the Prehistoric Society, 53: 351-362.

Bradley, R 1988 'Hoarding, recycling and the consumption of prehistoric metalwork: Technological change in western Europe'.
World Archaeology 20(2): 249-260, DOI: http://dx.doi.org/10.1080/00438243.198 8.9980070

Bradley, R 1990 The Passage of Arms: An Archaeological Analysis of Prehistoric Hoards and Votive Deposits. Cambridge: Cambridge University Press.

Bradley, R 2003 'A life less ordinary: The ritualization of the domestic sphere in later prehistoric Europe'. Cambridge Archaeological Journal 13(1): 5-23, DOI: http://dx.doi. org/10.1017/S0959774303000015

Bradley, R 2005 Ritual and Domestic Life in Prehistoric Europe. London: Routledge.

Brück, J 1999 'Ritual and rationality: Some problems of interpretation in European archaeology'. European Journal of Archaeology 2(3): 313-344, DOI: http://dx.doi. org/10.1177/146195719900200303

Brudenell, M and Cooper, A J 2008 'Postmiddenism: Depositional histories on later bronze age settlements at Broom, Bedfordshire'. Oxford Journal of Archaeology 27(1): 15-36, DOI: http://dx.doi. org/10.1111/j.1468-0092.2007.00293.x

Budd, P and Taylor, T 1995 'The faerie smith meets the bronze industry: Magic versus science in the interpretation of prehistoric metal-making'. World Archaeology 27(1): 133-143, DOI: http://dx.doi.org/10.1080 /00438243.1995.9980297

Chapman, J 2000 Fragmentation in Archaeology: People, Places and Broken Objects in the Prehistory of South-Eastern Europe. London: Routledge.

Clarke, S 1997 'Abandonment, rubbish disposal and "special" deposits at Newstead'. In TRAC 96: Proceedings of the Sixth Annual Theoretical Roman Archaeology Conference, Hosted by The Research School of Archaeology and Archaeological Science, The University of Sheffield, March 30th and 31st 1996. Meadows, K, Lemke, $\mathrm{C}$ and Heron, J (eds.). Oxford: Oxbow, 73-81.

Cookson, N 1992 'Treasure Trove: Dumb enchantment or new law?'. Antiquity 66(251): 399-405. 
Cunliffe, B 1992 'Pits, preconceptions and propitiation in the British Iron Age'. Oxford Journal of Archaeology 11(1): 69-83, DOI: http://dx.doi. org/10.1111/j.1468-0092.1992.tb00257.x

Davenport, W H 1986 'Two kinds of value in the Eastern Solomon Islands'. In The Social Life of Things: Commodities in Cultural Perspective. Appadurai, A (ed.). Cambridge: Cambridge University Press, 95-109.

Ducmane, K and Ozolina, A 2009 Latvija Eiropā: Monētu depoz̄iti 1.-20. gadsimtā. Rīga: Latvijas Nacionālais Vēstures Muzejs.

Fontijn, D R 2002 Sacrificial Landscapes: Cultural Biographies of Persons, Objects and Natural Places in the Bronze Age of the Southern Netherlands, c.2300-600 BC 2001. Leiden: Faculty of Archaeology, University of Leiden.

Fontijn, D R 2008 “"'Traders" hoards': Reviewing the relationship between trade and permanent deposition: the case of the Dutch Voorhout hoard'. In Hoards from the Neolithic to the Metal Ages: Technical and Codified Practices: Session of the XIth Annual Meeting of the European Association of Archaeologists. Hamon, C and Quilliec, B (eds.). BAR international series, 1758. Oxford: Archaeopress, 5-17.

Geißlinger, H 1984 'Depotfund. Hortfund'. In Reallexikon der germanischen Altertumskunde. Vol. 5. Hoops, J. (ed.). Berlin: de Gruyter, 320-338.

Gerrard, J 2009 'The Drapers' Gardens hoard: A preliminary account'. Britannia 40: 163-183.

Hamerow, H 2006 "'Special deposits" in Anglo-Saxon settlements'. Medieval Archaeology, 50: 1-30, DOI: http://dx.doi.org/ 10.1179/174581706x124211

Hammond, G N 1982 'Treasure trove: Ancient law to preserve archaeological relics'. Antiquity 56(216): 58-60.

Hamon, C and Quilliec, B 2008 'Hoards from the Neolithic to the Metal Ages: Technical and codified practices: Introduction'. In Hoards from the Neolithic to the Metal Ages: Technical and Codified Prac- tices: Session of the XIth Annual Meeting of the European Association of Archaeologists. Hamon, C and Quilliec, B (eds.). BAR international series, 1758. Oxford: Archaeopress, 1-4.

Hamon, C and Quilliec, B (eds.) 2008 Hoards from the Neolithic to the Metal Ages: Technical and Codified Practices: Session of the XIth Annual Meeting of the European Association of Archaeologists. BAR international series, 1758. Oxford: Archaeopress.

Hårdh, B 1996 Silver in the Viking Age: A Regional-Economic Study. Stockholm: Almquist and Wiksell International.

Härke, H 1997 'Early Anglo-Saxon social structure'. In The Anglo-Saxons from the Migration Period to the Eighth Century: An Ethnographic Perspective. Hines, J (ed.). Studies in historical archaeoethnology. Woodbridge: Boydell Press, 125-170.

Haselgrove, C 1982 'Wealth, prestige and power: The dynamics of Late Iron Age political centralisation in south-east England'. In Ranking, Resource and Exchange : Aspects of the Archaeology of Early European Society. Renfrew, C and Shennan, S (eds.). Cambridge: Cambridge University Press, 79-88.

Haselgrove, C and Wigg-Wolf, D 2005 'Introduction: Iron Age coinage and ritual practices'. In Iron Age Coinage and Ritual Practices. Haselgrove, C and Wigg-Wolf, D (eds.). Studien zu Fundmünzen der Antike, 20. Mainz: P. von Zabern, 9-22.

Hausmann, R 1905 'Eine Bronze-Depotfund mit einer römischen Bronze-Lampe, gefunden zu Kawwast bei Dorpat'. Sitzungsberichten der Gesellschaft für Geschichte und Altertumskunde der Ostseeprovinzen Russland für das Jahr 1905: 64-74.

Hausmann, R 1914 'Der Depotfund von Dorpat'. In Baltische Studien zur Archäologie und Geschichte. Arbeiten des Baltischen Vorbereitenden Komitees für den XVI. Archäologischen Kongress in Pleskau 1914. Herausgegeben von der Gesellschaft für Geschichte und Altertumskunde der Ostseeprovinzen Russlands. Riga: G. Reimer, 97-116. 
Hedeager, L 1992 Iron-Age Societies: From Tribe to State in Northern Europe, 500 BC to $A D$ 700. Oxford: Blackwell.

Hedeager, L 1999 'Sacred topography. Depositions of wealth in the cultural landscape'. In Glyfer och Arkeologiska Rum: En Vänbok till Jarl Nordbladh. Gustafsson, A and Karlsson, H (eds.). Gotarc. Series A, 3. Göteborg: Göteborg University, Department of Archaeology.

Hedeager, L 2011 Iron Age Myth and Materiality: An Archaeology of Scandinavia, $A D$ 400-1000. London: Routledge.

Hill, J D 1995 Ritual and Rubbish in the Iron Age of Wessex: A Study on the Formation of a Specific Archaeological Record. BAR British series, 242. Oxford: Tempus Reparatum.

Hines, J 1989 'Ritual hoarding in migrationperiod Scandinavia: A review of recent interpretations'. Proceedings of the Prehistoric Society 55: 193-205.

Hingley, R 2006 'The Deposition of iron objects in Britain during the later prehistoric and Roman periods: Contextual analysis and the significance of iron'. Britannia 37: 213-257.

Ilkjær, J 2002 'Den bevidste ødelæggelse i krigsbytteofringerne'. In Plats och Praxis: Studier av Nordisk Förkristen Ritual. Jennbert, K, Andrén, A and Raudvere, C (eds.). Vägar till Midgård, 2. Lund: Nordic Academic Press, 203-14.

Jaanits, L, Laul, S, Lõugas, V and Tõnisson, E 1982 Eesti Esiajalugu, Tallinn: Eesti raamat.

Johns, C 1994 'Romano-British preciousmetal hoards: some comments on Martin Millett's paper'. In TRAC 94: Proceedings of the Fourth Annual Theoretical Roman Archaeology Conference, held at the Department of Archaeology, University of Durham, 19th and 20th March, 1994. Cottam, S, Dungworth, D, Scott, S and Taylor, J (eds.). Oxford: Oxbow, 107-117.

Johns, C 1996 'The classification and interpretation of Romano-British treasures'. Britannia 27: 1-16.

Jørgensen, L, Storgaard, B and Thomsen, L G (eds.) 2003 The Spoils of Victory: The
North in the Shadow of the Roman Empire. Copenhagen: Nationalmuseet.

Joyce, R A 2008 'Practice in and as deposition'. In Memory Work: Archaeologies of Material Practices. Mills, B J and Walker, W H (eds.). School for Advanced Research advanced seminar series. Santa Fe: School for Advanced Research Press, 25-39.

Joyce, R and Pollard, J 2010 'Archaeological assemblages and practices of deposition'. In The Oxford Handbook of Material Culture Studies. Oxford handbooks. Hicks, D and Beaudry, M C (eds.). Oxford: Oxford University Press, 291-309.

Keane, W 2001 'Money is no object: Materiality, desire, and modernity in an Indonesian Society'. In The Empire of Things: Regimes of Value and Material. Myers, F R (ed.). School of American Research advanced seminar series. Santa Fe: School of American Research Press, 65-90.

Kopytoff, I 1986 'The cultural biography of things: Commoditization as process'. In The Social Life of Things: Commodities in Cultural Perspective. Appadurai, A (ed.). Cambridge: Cambridge University Press, 64-91.

LAA III (Rimantienè, R (ed.)) 1977 Lietuvos TSR Archeologijos Atlasas, III. I-XIII a. Pilkapynai ir Senkapiai. Vilnius: Mintis.

Lang, V 1996 Muistne Rävala. Muistised, Kronoloogia ja Maaviljelusliku Asustuse Kujunemine Loode-Eestis, Eriti Pirita Jõe Alamjooksu Piirkonnas. I-II. Muinasaja teadus, 4. Tallinn: Ajaloo Instituut.

Lang, V 2007a Baltimaade Pronksi- ja Rauaaeg. Tartu: Tartu Ülikooli Kirjastus.

Lang, V 2007b The Bronze and Early Iron Ages in Estonia. Estonian Archaeology, 3. Tartu: Tartu University Press.

Lesure, $\mathbf{R} 1999$ 'On the genesis of value in early hierarchical societies'. In Material Symbols: Culture and Economy in Prehistory. Robb, J E (ed.). Occasional paper (Southern Illinois University at Carbondale. Center for Archaeological Investigations), 26. Carbondale: Center for Archaeological Investigations, Southern Illinois University, 23-55. 
Levy, J E 1982 Social and Religious Organization in Bronze Age Denmark: An Analysis of Ritual Hoard Finds. BAR international series, 124. Oxford: B.A.R.

Lillios, K T 1999 'Objects of memory: The ethnography and archaeology of heirlooms'. Journal of Archaeological Method and Theory 6(3): 235-262, DOI: http:// dx.doi.org/10.1023/A:1021999319447

Lõugas, V 1996 Kaali Kraatriväljal Phaethonit Otsimas. Tallinn: Eesti Entsüklopeediakirjastus.

Lucero, L J 2008 'Memorializing place among classic Maya commoners'. In Memory Work: Archaeologies of Material Practices. Mills, B J and Walker, W H (eds.). School for Advanced Research advanced seminar series. Santa Fe: School for Advanced Research Press, 187-205.

Mandel, M and Tamla, T 1977 'Rikassaare relvaleid'. ENSV Teaduste Akadeemia Toimetised. Ühiskonnateadused 26(2): 158-164.

Manning, W H 1972 'Ironwork hoards in Iron Age and Roman Britain'. Britannia 3: 224-250.

Michelbertas, M 2001 Corpus der römischen Funde im europäischen Barbaricum: Litauen. Vilnius: Universität Vilnius Lehrstuhl für Archäologie.

Miller, D 2001 'Alienable gifts and inalienable commodities'. In The Empire of Things: Regimes of Value and Material. Myers, F R (ed.). School of American Research advanced seminar series. Santa Fe: School of American Research Press, 91-115.

Millett, M 1994 'Treasure: Interpreting Roman hoards'. In TRAC 94: Proceedings of the Fourth Annual Theoretical Roman Archaeology Conference, held at the Department of Archaeology, University of Durham, 19th and 20th March, 1994. Cottam, S, Dungworth, D, Scott, S and Taylor, J (eds.). Oxford: Oxbow, 99-106.

Mills, B J 2004 'The establishment and defeat of hierarchy: Inalienable possessions and the history of collective prestige structures in the pueblo southwest'. American Anthropologist 106(2): 238-251, DOI: http:// dx.doi.org/10.1525/aa.2004.106.2.238
Mills, B J and Walker, W H 2008 Introduction: Memory, materiality, and depositional practice. In Memory Work: Archaeologies of Material Practices. Mills, B J and Walker, W H (eds.). School for Advanced Research advanced seminar series. Santa Fe: School for Advanced Research Press, 3-23.

Moora, H 1925 'Hõbeaare Pilistverest'. Eesti Rahva Muuseumi Aastaraamat 1: 110-117.

Moora, H 1935 'Der Verwahrfund von Piilsi, Kirchspiel Avinurme'. Õpetatud Eesti Seltsi Aastaraamat 1933: 283-303.

Moora, H (Moopa, X) 1962 'Клад V века, найденный в Реола близ гор. Тарту'. Swiatowit XXIV(1962): 343-351.

Moore, H L 1982 'The interpretation of spatial patterning in settlement residues'. In Symbolic and Structural Archaeology. Hodder, I (ed.). Cambridge: Cambridge University Press, 74-79.

Morris, J and Jervis, B 2011 'What's so special? A reinterpretation of Anglo-Saxon 'special deposits". Medieval Archaeology 55(1): 66-81.

Myers, F R 2001 'Introduction: The empire of things'. In The Empire of Things: Regimes of Value and Material. Myers, F R (ed.). School of American Research advanced seminar series. Santa Fe: School of American Research Press, 3-61.

Needham, S P 1988 Selective deposition in the British Early Bronze Age. World Archaeology 20(2): 229-248, DOI: http:// dx.doi.org/10.1080/00438243.1988.998 0069

Oras, E 2009 Eesti keskmise rauaaja peitvarad. Magistritöö. MA thesis. LundTartu: Tartu Ülikool: University of Tartu.

Oras, E 2010 'Ritual wealth deposits in Estonian Middle Iron Age material'. Estonian Journal of Archaeology 14(2): 123-142.

Osborne, R2004 'Hoards, votives, offerings: The archaeology of the dedicated object'. World Archaeology 36(1): 1-10, DOI: http://dx.doi. org/10.1080/0043824042000192696

Oxford English Dictionary (Online), http://www.oed.com/ (Accessed on 10th January 2012). 
Parker Pearson, M 1999 The Archaeology of Death and Burial. Stroud: Sutton.

Pauketat, T R and Alt, S M 2004 'The making and meaning of a Mississippian axehead cache'. Antiquity 78(302): 779-797.

Peets, J 2003 The Power of Iron: Iron Production and Blacksmithy in Estonia and Neighbouring Areas in Prehistoric Period and the Middle Ages = Raua Vägi: Raua Tootmine ja Sepatöö Eestis ja Naaberpiirkondades Muinas- ja Keskajal. Muinasaja teadus 12. Tallinn: Teaduste Akadeemia Kirjastus.

Pollard, J 1995 'Inscribing space: Formal deposition at the later Neolithic monument of Woodhenge, Wiltshire'. Proceedings of the Prehistoric Society 61: 137-156.

Pollard, J 2001 'The aesthetics of depositional practice'. World Archaeology 33(2): 315-333, DOI: http://dx.doi.org/10.1080/ 00438240120079316

Pollard, J 2008 'Deposition and Material Agency in the Early Neolithic of Southern Britain'. In Memory Work: Archaeologies of Material Practices. Mills, B J and Walker, W H (eds.). School for Advanced Research advanced seminar series. Santa Fe: School for Advanced Research Press, 41-59.

Quast, D and Tamla, Ü (with contribution by Felten, S) 2010 'Two fifth century ad Byzantine silver bowls from Estonia'. Estonian Journal of Archaeology, 14(2), 99-122, DOI: http://dx.doi.org/10.3176/arch.2010.2.01

Randsborg, K 2002 'Wetland hoards'. Oxford Journal of Archaeology 21(4): 415-418, DOI: http://dx.doi.org/10.1111/1468-0092.00171

Reece, R 1988 'Interpreting Roman hoards'. WorldArchaeology 20(2):261-269, DOI: http:// dx.doi.org/10.1080/00438243.1988.9980071

Renfrew, C 1986 'Varna and the emergence of wealth in prehistoric Europe'. In The Social Life of Things: Commodities in Cultural Perspective. Appadurai, A (ed.). Cambridge: Cambridge University Press, 141-168.

Richards, C and Thomas, J 1984 'Ritual activity and structured deposition in later Neolithic Wessex'. In Neolithic Studies: A
Review of Some Current Research. Bradley, $\mathrm{R}$ and Gardiner, J (eds.). BAR British series, 133. Oxford: B.A.R. 189-218.

Rowlands, M J 1971 'The archaeological interpretation of prehistoric metalworking'. World Archaeology 3(2): 210-224, DOI: http://dx.doi.org/10.1080/0043824 3.1969.9979502

Schmiedehelm, M 1934 'Keskmise rauaaja aardeleide Kambjast'. Eesti Rahva Мuuseumi Aastaraamat 9-10: 210-224.

Samson, AVM 2006 'Offshore finds from the Bronze Age in North-Western Europe: The shipwreck scenario revisited'. Oxford Journal of Archaeology 25(4): 371-388, DOI: http://dx.doi.org/10.1111/j.14680092.2006.00267.x

Sparrow, C 1982 'Treasure Trove: A lawyer's view'. Antiquity 56(218): 199-202, http://antiquity.ac.uk/Ant/056/0199/ Ant0560199.pdf.

Stjernquist, B 1997 The Röekillorna Spring. Spring-Cults in Scandinavian Prehistory. Stockholm: Almqvist and Wiksell International.

Tallgren, A M 1924 'Ein wichtiger eisenzeitlicher Fund aus Kunilepa Ksp. Juuru (Jörden)'. Sitzungsberichte der Gelehrten Estnischen Gesellschaft 1923: 50-56.

Tamla, T 1977 'Eesti soo- ja rabaleidudest'. Tartu Riikliku Ülikooli ÜTÜ ajalooringi kogumik. Ajalooalaseid töid VI: 151-175.

Tamla, Ü and Kiudsoo, M 2005 Eesti Muistsed Aarded: Näituse Kataloog: 19.05.2005 - 05.06.2006 Tallinnas. Tallinn: Arheoloogiakeskus.

The Treasure (Designation) Order 2002 (Online), http://www.legislation.gov.uk/uksi /2002/2666/contents/made (Accessed on 10th January 2012).

Thomas, J 1999 'An economy of substances in earlier Neoltihic Britain'. In Material Symbols: Culture and Economy in Prehistory. Robb, J E (ed.). Occasional paper (Southern Illinois University at Carbondale. Center for Archaeological Investigations), 26. Carbondale: Center for Archaeological Investigations, Southern Illinois University, 70-89. 
Tõnisson, E 1962 'Eesti aardeleiud 9.-13. sajandist'. In Muistsed Kalmed ja Aarded. Moora, H (ed.). Arheoloogiline Kogumik, 2. Tallinn: Ajaloo Instituut, Eesti NSV Teaduste Akadeemia, 182- 274.

Treasure Act 1996 (Online) http://www. legislation.gov.uk/ukpga/1996/24/contents (Accessed on 10th January 2012).

Urtāns, V 1964 'Latvijas 5.-9. gs. depozīti'. Arheoloǵija un Etnogrāfija VI: 39-74.

Urtāns, V 1977 Senākie Depozìti Latvijā l̄idz 1200. g. Riga: Zinatne.

Van Rossenberg, E 2003 'Embedding material culture in perceptions of landscape. A contextual analysis of the deposition of bronzes in Northern Italy'. In SOMA 2002. Symposium On Mediterranean Archaeology. Proceedings of the Sixth Annual Meeting of Postgraduate Researchers. University of Glasgow, Department of Archaeology, 15-17 February, 2002, Glasgow. Brysbaert, A, de Bruijn, N, Gibson, E, Michael, A and Monaghan, $M$ (eds.). BAR international series, 1142. Oxford: Archaeopress, 157-164.

Verlaeckt, K 2000 'Hoarding and the circulation of metalwork in Late Bronze Age Denmark: quantification and beyond'.
In Metals Make the World Go Round: The Supply and Circulation of Metals in Bronze Age Europe: Proceedings of a Conference Held at the University of Birmingham in June 1997. Pare, C F E (ed.). Oxford: Oxbow Books, 194-208.

Walker, W H 1995 'Ceremonial trash?' In Expanding Archaeology. Skibo, J M, Walker, W H and Nielsen, A E (eds.). Salt Lake City: University of Utah Press, 67-79.

Weiner, A B 1992 Inalienable Possessions: The Paradox of Keeping-While-Giving. Berkeley : University of California Press.

Wentink, K and Van Gijn, A 2008 'Neolithic depositions in the northern Netherlands'. In Hoards from the Neolithic to the Metal Ages: Technical and Codified Practices: Session of the XIth Annual Meeting of the European Association of Archaeologists. Hamon, C and Quilliec, B (eds.). BAR international series, 1758. Oxford: Archaeopress, 29-34.

Yates, D and Bradley, R 2010 'Still water, hidden depths: The deposition of Bronze Age metalwork in the English Fenland'. Antiquity 84(324): 405-415, http://antiquity.ac.uk/ant/84/ant840405.htm 